\title{
Polyacrylamide Gel Electrophoresis of Whole-Cell Proteins of Porcine Strains of Haemophilus
}

\author{
J. NICOLET, Ph. PAROZ, AND M. KRAWINKLER \\ Institute of Veterinary Bacteriology, University of Berne, CH-3012 Berne, Switzerland
}

\begin{abstract}
The protein patterns of sodium dodecyl sulfate-solubilized whole cells of porcine strains of Haemophilus were studied by using polyacrylamide gel electrophoresis. The pattern of Haemophilus pleuropneumoniae was very homogenous and was independent of the serological type. At least two different patterns could be distinguished in Haemophilus parasuis, suggesting some heterogeneity in this species. The results were highly reproducible and were not affected by growth conditions. Comparable patterns were obtained after solubilization with sodium taurocholate and sodium carbonate and after ultrasonic treatment, but not after phenol-acetic acid extraction. In addition, we compared porcine strains with human strains (Haemophilus influenzae, Haemophilus parahaemolyticus) and also with some bacteria of the genera Pasteurella, Actinobacillus, Brucella, Moraxella, and Bordetella. The species-specific picture is given mostly by the pattern of a group of proteins with molecular weights just above 68,000 (Haemophilus) and in the region of molecular weights between 23,000 and 40,000 and between 15,000 and 17,000 (Haemophilus, Pasteurella, Actinobacillus). These observations suggest the possible use of this method as an aid in studying the taxonomy of these bacteria.
\end{abstract}

The electrophoretic patterns obtained by polyacrylamide gel electrophoresis (PAGE) of cell proteins from bacteria has proved to be useful in taxonomic studies. Since these cell proteins are genetically directed, their patterns tend to express genetic relationships between microorganisms (29).

In recent years, reports have been published on the use of PAGE with a great variety of microorganisms, ranging from mycoplasmas (5, $6,27-29,40)$ to bacteria and even fungi (Aspergillus fumigatus) (38); the bacteria have included brucellae (20), staphylococci (3), enteric bacteria $(26,30,32,33,44)$, streptomycetes (7), yersiniae (10), mycobacteria (8), streptococci $(17,18)$, campylobacters (vibrios) $(21)$, neisseriae $(24,31,45)$, Corynebacterium diphtheriae (16), Erysipelothrix rhusiopathiae (43), and Pasteurella haemolytica (42). For the genus Haemophilus, only a few studies of this type have been reported. Neumann and Hinz (22) found that the protein patterns of strains of Haemophilus paragallinarum, Haemophilus avium, Haemophilus parainfluenzae, and Haemophilus parasuis are quite different, even among strains within the same species, so that the method has been judged to be unreliable for taxonomic purposes.

It has been clearly demonstrated that the cytoplasmic membranes and whole-cell proteins of mycoplasmas and also of L-forms of bacteria show highly reproducible and species-specific electrophoretic patterns with PAGE $(28,39,40)$.
It is likely in such cases that PAGE can be used as a taxonomic tool. In the case of other bacteria, the majority of authors have observed similarities in the electrophoretic patterns within a genus $(20,32,41)$ or within a species $(7,8,10,18$, $20,24,31,42)$ but not between genera $(20,32$, 41).

Despite the rather complex structure of bacterial cells, the observations cited above tend to confirm the usefulness of PAGE in studying the genetic relationships of bacteria. However, a few incongruous results $(17,24,43)$ cast some doubts on the prudence of accepting PAGE patterns of whole-cell proteins as taxonomically useful. These incongruities point out the need for standardizing the solubilization and electrophoretic methods, as well as the need for a better knowledge of the influence of growth conditions on bacterial cell composition. It has been shown (1, $11,12,34-37,46$ ) that bacterial cytoplasmic membranes and outer membrane proteins may have some influence on the protein patterns. The purpose of the study reported here was to determine the electrophoretic patterns of wholecell proteins from Haemophilus strains of porcine origin and the relationship of these patterns to those of some human strains of Haemophilus and of organisms in other genera.

\section{MATERIALS AND METHODS}

Bacterial strains. The strains used in this study are listed in Table 1.

Bacterial suspensions. Bacteria were cultured on 
TABLE 1. List of strains used in this study

\begin{tabular}{|c|c|c|c|c|}
\hline Laboratory no. & Name & $\begin{array}{l}\text { Strain and/or sero- } \\
\text { var designation }\end{array}$ & Source ${ }^{a}$ & Lesion \\
\hline & H. parasuis & A 9 & & $?$ \\
\hline & H. parasuis & B 26 & & ? \\
\hline & H. parasuis & C 5 & 1 & $?$ \\
\hline & H. parasuis & D 74 & & ? \\
\hline 1597 & H. parasuis & & 2 & Pneumonia (pig) \\
\hline 899 & H. parasuis & & & Pneumonia (pig) \\
\hline 1163 & H. parasuis & & & Glässer disease (pig) \\
\hline 1068 & H. parasuis & & & Glässer disease (pig) \\
\hline 1500 & H. parasuis & & & Glässer disease (pig) \\
\hline 1722 & H. parasuis & & 2 & Glässer disease (pig) \\
\hline 1598 & H. parasuis & & & Glässer disease (pig) \\
\hline 1384 & $H$. parasuis & & & Glässer disease (pig) \\
\hline $4074^{b}$ & H. pleuropneumoniae & $\begin{array}{l}\text { Serovar } \\
\text { ATCC } 27088\end{array}$ & 2 & $\begin{array}{l}\text { Contagious pleuropneu- } \\
\text { monia (pig) }\end{array}$ \\
\hline S 1535 & H. pleuropneumoniae & $\begin{array}{rr}\text { Serovar } & 2, \\
\text { ATCC } 27089\end{array}$ & 2 & $\begin{array}{l}\text { Contagious pleuropneu- } \\
\text { monia (pig) }\end{array}$ \\
\hline S 1421 & H. pleuropneumoniae & $\begin{array}{r}\text { Serovar } 3, \\
\text { ATCC } 27090\end{array}$ & 2 & $\begin{array}{l}\text { Contagious pleuropneu- } \\
\text { monia (pig) }\end{array}$ \\
\hline M 62 & H. pleuropneumoniae & Serovar 4 & 3 & $\begin{array}{c}\text { Contagious pleuropneu- } \\
\text { monia (pig) }\end{array}$ \\
\hline K 17 & H. pleuropneumoniae & Serovar 5 & 3 & Arthritis (lamb) \\
\hline $2538 / 4$ & H. pleuropneumoniae & Serovar 1 & Australia (4) & $\begin{array}{l}\text { Contagious pleuropneu- } \\
\text { monia (pig) }\end{array}$ \\
\hline S 447 & H. pleuropneumoniae & Serovar 2 & Switzerland (2) & $\begin{array}{l}\text { Contagious pleuropneu- } \\
\text { monia (pig) }\end{array}$ \\
\hline HP 8 & H. pleuropneumoniae & Serovar 2 & Japan (4) & $\begin{array}{c}\text { Contagious pleuropneu- } \\
\text { monia (pig) }\end{array}$ \\
\hline S 43 & H. pleuropneumoniae & Serovar 3 & Switzerland (2) & $\begin{array}{c}\text { Contagious pleuropneu- } \\
\text { monia (pig) }\end{array}$ \\
\hline 12960 & H. pleuropneumoniae & Serovar 5 & Holland (4) & $\begin{array}{l}\text { Contagious pleuropneu- } \\
\text { monia (pig) }\end{array}$ \\
\hline 95905 & H. pleuropneumoniae & Serovar 5 & Taiwan (4) & $\begin{array}{l}\text { Contagious pleuropneu- } \\
\text { monia (pig) }\end{array}$ \\
\hline 266-1970HAE & H. pleuropneumoniae & Serovar 5 & Belgium (4) & $\begin{array}{l}\text { Contagious pleuropneu- } \\
\text { monia (pig) }\end{array}$ \\
\hline Greenfield & H. pleuropneumoniae & Serovar 5 & Canada (4) & $\begin{array}{l}\text { Contagious pleuropneu- } \\
\text { monia (pig) }\end{array}$ \\
\hline L 349 & Haemophilus sp. & Minor group & 4 & Pneumonia (pig) \\
\hline LW 202 & $\begin{array}{l}\text { Haemophilus sp. } \\
\text { H. influenzae }\end{array}$ & $\begin{array}{l}\text { Minor group } \\
\text { b (51) }\end{array}$ & $\begin{array}{l}4 \\
5\end{array}$ & $\begin{array}{l}\text { Pneumonia (pig) } \\
\text { ? (Human) }\end{array}$ \\
\hline & H. parahaemolyticus & 536 & 6 & ? (Human) \\
\hline S 847 & Pasteurella multocida & Type A & 2 & Pneumonia (pig) \\
\hline W 241 & $\begin{array}{l}\text { Pasteurella haemolyt- } \\
\text { ica }\end{array}$ & & 2 & Pneumonia (sheep) \\
\hline W 702 & $\begin{array}{l}\text { Actinobacillus ligni- } \\
\text { eresii }\end{array}$ & & 2 & Abscess (cattle) \\
\hline S 302 & $\begin{array}{l}\text { Actinobacillus ligni- } \\
\text { eresii (hemolytic var- } \\
\text { iant) }\end{array}$ & & 2 & Pneumonia (pig) \\
\hline & $\begin{array}{l}\text { Brucella abortus } \\
\text { Moraxella bovis }\end{array}$ & $\begin{array}{l}\text { W } 99 \\
\text { NCTC } 9426\end{array}$ & $\begin{array}{l}7 \\
8\end{array}$ & $\begin{array}{l}\text { ? (Cattle) } \\
\text { ? (Cattle) }\end{array}$ \\
\hline S 485 & $\begin{array}{l}\text { Bordetella bronchisep- } \\
\quad \text { tica }\end{array}$ & & 2 & Atrophic rhinitis (pig) \\
\hline
\end{tabular}

${ }^{a}$ Sources: 1, K. Bakos, Veterinärmedicinska Anstalt, Stockholm, Sweden; 2, our own isolates; 3, E. L. Biberstein, University of California, Davis; 4, source as mentioned in Kilian et al. (15); 5, T. Omland, University of Oslo, Oslo, Norway; 6, M. Pittman, National Institutes of Health, Bethesda, Md.; 7, Central Veterinary Laboratory, Weybridge, England; 8, S. D. Henriksen, University of Oslo.

${ }^{b}$ Proposed neotype strain (15). 
chocolate agar (10\% sheep blood in blood agar base [Oxoid] heated at $80^{\circ} \mathrm{C}$ for $10 \mathrm{~min}$ in two steps). For comparative purposes we also used brain heart infusion agar (Difco Laboratories) enriched with 1.25\% yeast extract (Fleishman active dry yeast) and Trypticase soy agar (BBL Microbiology Systems) mixed with $10 \mu \mathrm{g}$ of nicotinamide adenine dinucleotide (Sigma Chemical Co.) per ml (NAD agar). The cells were harvested in saline and washed three times in saline.

Protein determination. The protein content of the bacteria was determined by the Hartree (9) modification of the Lowry method.

Preparation of bacterial extracts. (i) SDS solubilization. Washed bacteria were suspended in $0.0125 \mathrm{M}$ phosphate buffer ( $\mathrm{pH} 7.4$ ) containing $1 \%$ sodium dodecyl sulfate (SDS) and $1 \% \beta$-mercaptoethanol at a protein concentration of $1 \mathrm{mg} / \mathrm{ml}$, and the suspension was heated to boiling for $3 \mathrm{~min}$. Complete solubilization occurred. For comparison, solubilization was also done at $60^{\circ} \mathrm{C}$ for $1 \mathrm{~h}$ and at $37^{\circ} \mathrm{C}$ overnight.

(ii) Sodium taurocholate solubilization. Sodium taurocholate solubilization was performed by the method described by Omland (25). Washed bacteria were suspended in $0.005 \mathrm{M}$ phosphate buffer ( $\mathrm{pH} 7.4$ ) containing $0.005 \mathrm{M} \mathrm{NaCl}$ to give a concentration of 1 $\mathrm{mg}$ of cell protein per $\mathrm{ml}$. To this suspension was added 0.1 volume of a $10 \%$ solution of sodium taurocholate (prepared in distilled water). This mixture was incubated for $1 \mathrm{~h}$ in a water bath at $37^{\circ} \mathrm{C}$ and was centrifuged at $48,000 \times g$ for $45 \mathrm{~min}$. The supernatant was mixed with an equal volume of phosphate buffer containing $1 \%$ SDS.

(iii) Sodium carbonate solubilization. Sodium carbonate solubilization was performed by the method described by Omland (25). A suspension of $1 \mathrm{mg}$ of cell protein per $\mathrm{ml}$ was treated with $1 \%$ sodium carbonate for $1 \mathrm{~h}$ in a water bath at $37^{\circ} \mathrm{C}$. The $\mathrm{pH}$ was then lowered to 8.0 (from about 10.0) by adding $1 \mathrm{M}$ acetic acid. The suspension was then centrifuged at 48,000 $\times g$ for $\mathbf{4 5} \mathrm{min}$.

(iv) Ultrasonic disintegration. Washed bacteria were suspended in $0.01 \mathrm{M}$ phosphate buffer $(\mathrm{pH} 7.4)$ containing $0.14 \mathrm{M} \mathrm{NaCl}$ to give a concentration of 2 $\mathrm{mg}$ of cell protein per $\mathrm{ml}$. This suspension was treated with a Branson Sonifier at full output for $3 \mathrm{~min}$; the sample was maintained at $-30^{\circ} \mathrm{C}$ (methanol-water mixture with dry ice) to prevent overheating. The clear fluid of disrupted cells was mixed with an equal volume of phosphate buffer containing $1 \%$ SDS and $1 \% \beta$-mercaptoethanol.

Phenol-acetic-water extract. Phenol-acetic-water extract was performed as described by Razin and Rottem (29).

PAGE. For PAGE, the phosphate-buffered, $7.5 \%$ gel system described by Morowitz and Terry (19) was used; $1 \%$ SDS was added to the system, and the flat gel slab method, employing equipment from Biowerk (Biozentrum, Basel), was used. Samples (20 to $40 \mu \mathrm{l}$ ) of cell protein $(1 \mathrm{mg} / \mathrm{ml})$ were layered with $30 \%$ glycerol and subjected to electrophoresis at $100 \mathrm{~mA}$ for 3 h.

The slabs were stained for proteins with Coomassie brilliant blue $R$ (4). Alternatively, for phenol-acetic acid-water extracts, a gel system containing $5 \mathrm{M}$ urea (29) was used. For molecular weight standards, a mix- ture of the following reference substances was used: bovine serum albumin (molecular weight 68,000; Fluka, Buchs, Switzerland); catalase (60,000; Sigma); ovalbumin $(43,000$; Serva, Heidelberg, West Germany); pepsin (35,000; Sigma); trypsin (23,300; Sigma); myoglobin $(17,200$; Sigma); and hemoglobin $(15,500$; Sigma).

\section{RESULTS}

Electrophoretic patterns of porcine strains of Haemophilus. The protein patterns obtained with SDS-solubilized whole cells of the different Haemophilus strains of porcine origin included in this study are shown in Fig. 1. The interpretation of a specific pattern was based on $R_{f}$ values rather than on the intensity of the bands. We tentatively present in Fig. 1 a diagram of the overall patterns of $H$. parasuis and Hae. mophilus pleuropneumoniae. The most critical differences between the species of $H$. parasuis and $H$. pleuropneumoniae are in the patterns of groups of bands with molecular weights just above 68,000 and between 23,000 and 40,000 .

Within $H$. parasuis, there is a good deal of similarity among the major proteins of strains A, C, and D. However, quite a different pattern is evident for strain $\mathrm{B}$, especially in the $R_{f}$ value of a band of a molecular weight of about 37,000.

For the three serovars of $H$. pleuropneumoniae, the overall patterns are identical.

For the Haemophilus strains of the "minor group," two different patterns were obtained, suggesting heterogeneity within this group; strain L 349 seems to be closely related to $H$. pleuropneumoniae.

Effect of growth conditions. (i) Growth medium. With the growth from chocolate agar, brain heart infusion agar, and NAD agar, no differences in the major protein patterns of SDSsolubilized washed cell suspensions of $H$. pleuropneumoniae strains were detected.

(ii) Age of culture. Preliminary investigations with $H$. parasuis strain $\mathrm{A}$ and $H$. pleuropneumoniae showed that the length of incubation on chocolate agar had no marked influence on the overall cell protein pattern, even after $120 \mathrm{~h}$ of incubation. We observed, however, that in very young cultures $(5 \mathrm{~h})$ the quantity of highmolecular-weight proteins (molecular weights over 68,000 ) was less than in older cultures.

(iii) Fresh isolates and subcultures. The overall patterns of the major proteins of fresh isolates of $H$. pleuropneumoniae and $H$. parasuis did not differ significantly from those of the collection strains. Also, the use of subcultures had no effect on the patterns.

Effect of extraction procedure. The effects of classical solubilizing agents (SDS, sodium taurocholate, sodium carbonate, phenol-acetic acid extraction) and ultrasonic treatment on the sol- 


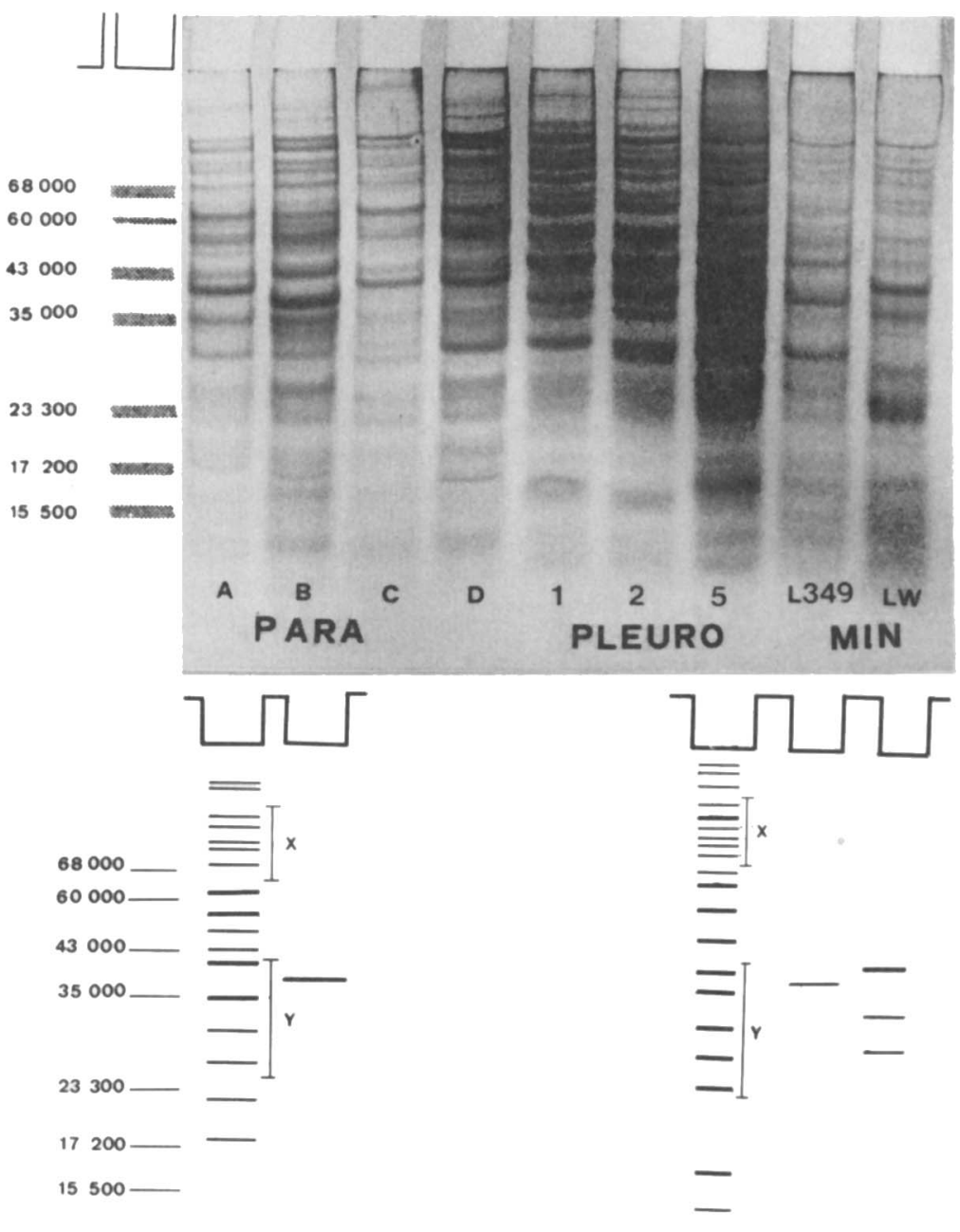

Fig. 1. PAGE of various SDS-solubilized porcine strains. PARA, H. parasuis types A, B, C, and D; PLEURO, H. pleuropneumoniae serovars 1, 2, and 5; MIN, Haemophilus sp. minor group. Below the gels are diagrams of the patterns of $H$. parasuis type $A$ and $H$. pleuropneumoniae with the species-specific groups of bands $(X$ and $Y$ ) in addition to the critical bands of $H$. parasuis type $B$ and Haemophilus sp. minor group. Numbers on the left are molecular weights.

ubilization of cells of $H$. pleuropneumoniae serovar 2 were compared in order to determine what effect, if any, the extraction procedure had on the protein patterns. Neither the different solubilization procedures nor the ultrasonic treatment had any influence on the protein pattern. However, SDS treatment provided a remarkably clear pattern, suggesting a more effective solubilization. On the other hand, extracts obtained after treatment with phenol-acetic acid could not be investigated with the PAGE system which we used because the loaded proteins migrated in the opposite direction. Inverting the electrodes produced a picture of very poor quality, one not comparable at all with the pictures obtained with the other extracts. Pictures obtained with the gel system containing $5 \mathrm{M}$ urea were inferior to those obtained with the SDS gel system.

We also investigated the possible effects of temperature and time of action of SDS on the solubilization procedure (boiling for $3 \mathrm{~min} ; 60^{\circ} \mathrm{C}$ for $1 \mathrm{~h}$, and $37^{\circ} \mathrm{C}$ overnight). Short boiling ( 3 min) offered the best representation of the highmolecular-weight proteins.

Electrophoretic patterns of diagnostic 
strains. (i) H. pleuropneumoniae. Figure 2 shows the electrophoretic patterns of eight strains of $H$. pleuropneumoniae; these strains were selected at random, but differences in serovar and geographic distribution were taken into consideration. The patterns were similar for all strains.

(ii) $H$. parasuis. Two strains (1597 and 899) freshly isolated from cases of pneumonia and six strains from Glässer disease were used. Figure 3 shows the electrophoretic patterns which distinguish between respiratory strains (strains 1597 and 899 ; related to the patterns of $H$. parasuis strains A, C, and D [critical bands in Fig. 1]) and

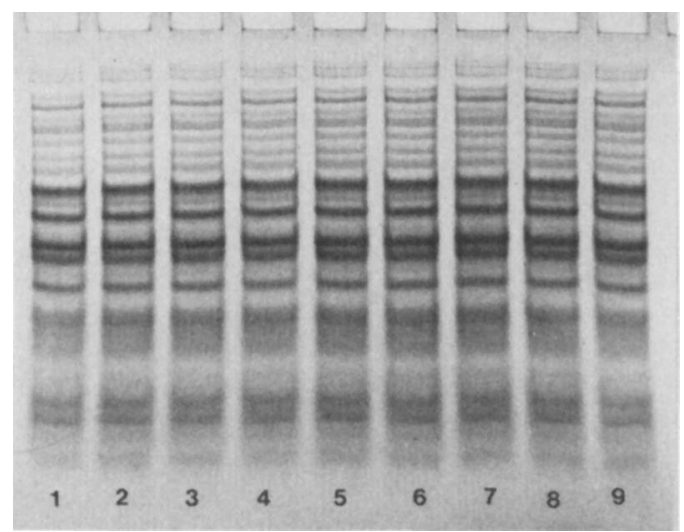

FIG. 2. PAGE of SDS-solubilized isolates of $H$. pleuropneumoniae from various countries. Gel 1, Serovar 1, (4074) from Argentina (proposed neotype); gel 2 , serovar 1 from Australia; gel 3, serovar 2 from Switzerland; gel 4, serovar 2 from Japan; gel 5, serovar 3 from Switzerland; gel 6, serovar 5 from Holland; gel 7, serovar 5 from Taiwan; gel 8, serovar 5 from Belgium; gel 9, serovar 5 from Canada.

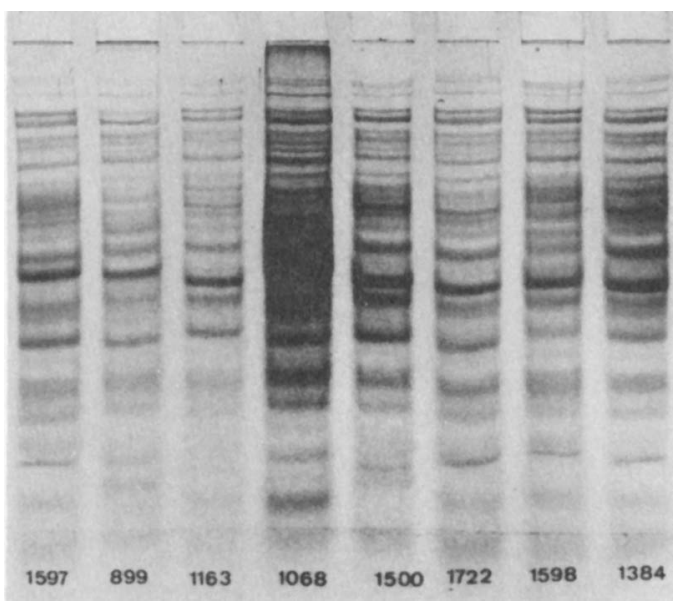

FIG. 3. PAGE of SDS-solubilized fresh isolates of H. parasuis.
Glässer strains (strains 1163, 1500, 1722, 1598, and 1384; related to $H$. parasuis strain $\mathrm{B}$ ). The pattern of strain 1068 (Glässer), although having some similarities to the patterns of the respiratory strains, seems to be unrelated to the pattern of any of the species.

Comparison of the protein patterns of Haemophilus species with those of other genera. Figure 4 shows a comparison of the

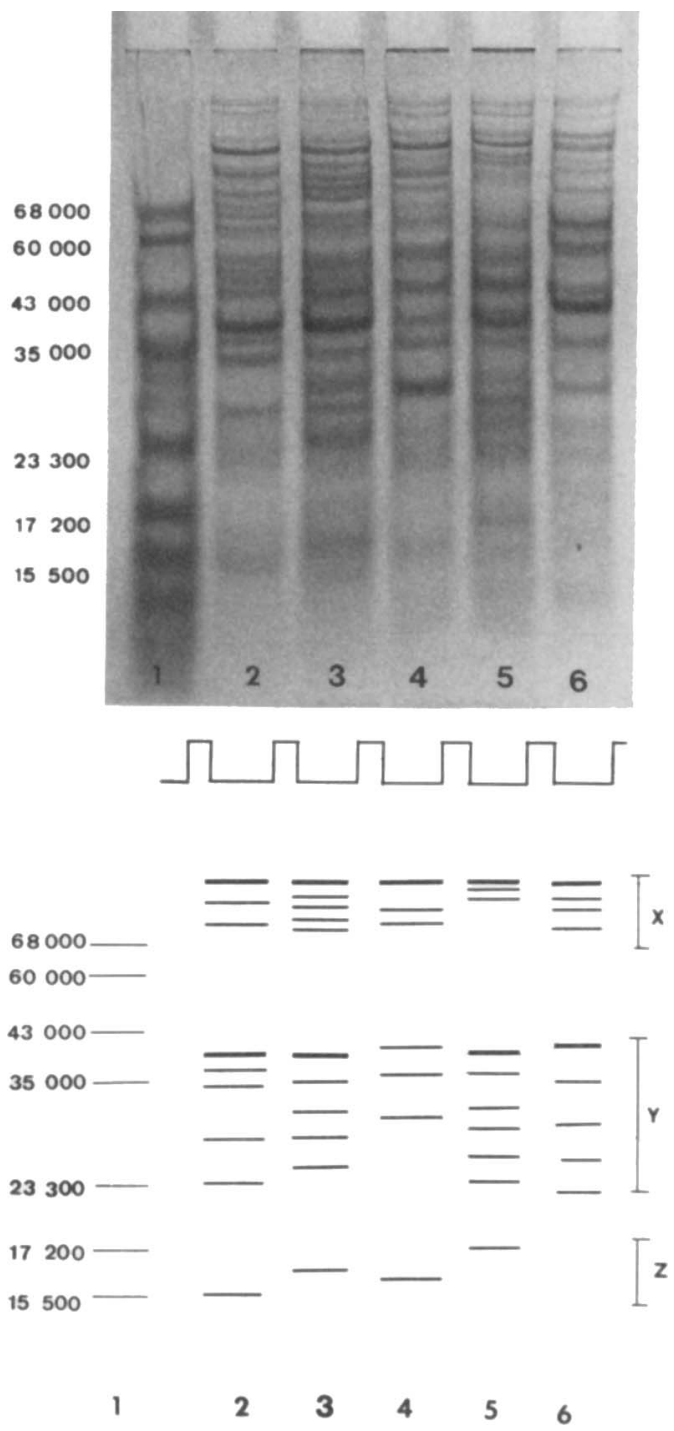

Fig. 4. Protein patterns of some Haemophilus strains. Gel 1, Molecular weight standard; gel 2, $H$. influenzae b strain 51 ; gel $3, H$. parahaemolyticus strain 536; gel 4, H. pleuropneumoniae strain S 1536; gel 5, Haemophilus sp. minor group strain 202; gel 6, $H$. parasuis strain A9. Below the gels are diagrams of the species-specific groups of bands $(X, Y$, and Z). Numbers on the left are molecular weights. 
protein patterns of $H$. influenzae b, $H$. parahaemolyticus, Haemophilus strains of the minor group, and $H$. parasuis. The main differences in the patterns occur in the regions of molecular weights just above 68,000 , between about 23,000 and 40,000 , and between 15,000 and 17,000.

In Fig. 5 strains of some Haemophilus species are compared with strains of Pasteurella, Actinobacillus, Brucella, Moraxella, and Bordetella. As within the genus Haemophilus, there is a similarity in the patterns of the more cathode-located proteins of strains of Pasteurella and Actinobacillus. However, this was not the case with strains of Brucella, Moraxella, and Bordetella. Despite the relative similarity in the patterns of some of the strains, the general protein pattern was quite specific for each strain examined. It is interesting to note that there are distinct pattern differences between Pasteurella multocida and P. haemolytica and between Actinobacillus lignieresii and its hemolytic variant, which in turn differs from $P$. haemolytica.

\section{DISCUSSION}

This study of the protein patterns of cells of porcine strains of Haemophilus shows that un-

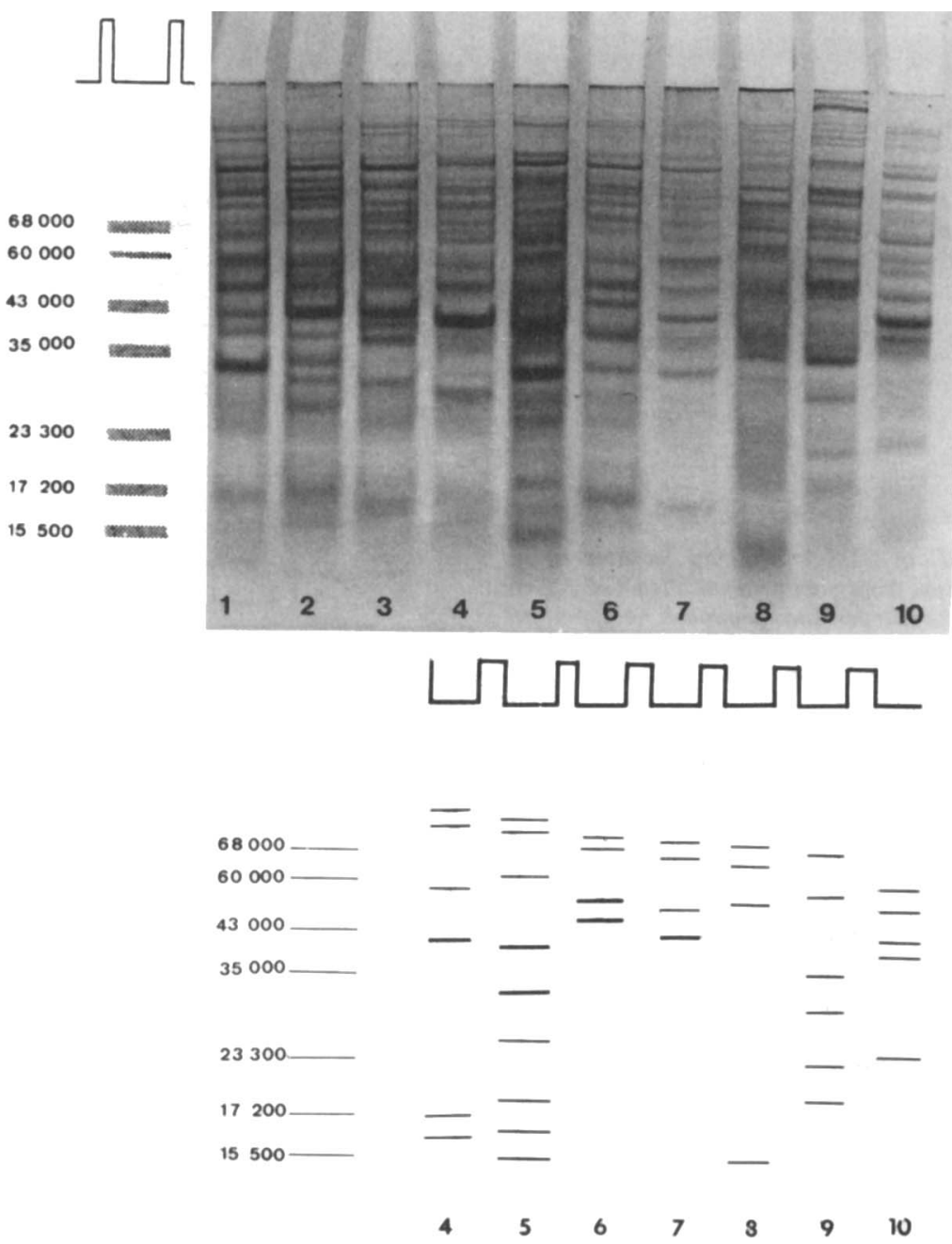

FIG. 5. Protein patterns of SDS-solubilized cells of some haemophili and other bacteria. Gel 1, H. pleuropneumoniae strain S 1536; gel 2, H. parahaemolyticus strain 536; gel 3, H. influenzae b; gel 4, Pasteurella multocida; gel 5, Pasteurella haemolytica; gel 6, Actinobacillus lignieresii (hemolytic); gel 7, Actinobacillus lignieresii; gel 8, Brucella abortus strain W 99; gel 9, Moraxella bovis; gel 10, Bordetella bronchiseptica. Below the gels are diagrams of species-specific patterns for the genera Pasteurella (lanes 4 and 5), Actinobacillus (lanes 6 and 7), Brucella (lane 8), Moraxella (lane 9), and Bordetella (lane 10). Numbers on the left are molecular weights. 
der standard conditions, a PAGE system employing SDS gels can provide highly reproducible results. Furthermore, the protein patterns are species specific, and the overall patterns are influenced neither by the growth conditions (type of medium, age of the culture, subcultures, etc.) nor by the methods of solubilizing the cells, except for treatment with phenol-acetic acid. This treatment seems to produce conditions of cell solubilization which are less than optimal for PAGE, explaining perhaps some of the misleading results obtained with $H$. paragallinarum and $H$. avium (22).

It is characteristic of Haemophilus cells to be solubilized easily by chemical agents, such as sodium taurocholate and sodium carbonate (25). Detergents, such as SDS, are also very efficient. This characteristic leads to a rapid and complete solubilization of cell proteins, which allows a high degree of reproduction of the electrophoretic pattern.

The electrophoretic pattern of the cell proteins of $H$. pleuropneumoniae is very specific and is independent of serological type. This is not surprising since serological specificity is due to capsular polysaccharides (23), which are not involved in protein determinations by PAGE. It is to be noted that at least one of the two strains of the minor group of haemophili shows a pattern definitely distinct from that of $H$. pleuropneumoniae, confirming the results of the study by Kilian et al. (15). The fact that the pattern of $H$. pleuropneumoniae is very different from that of $H$. parahaemolyticus is a further confirmation of the distinctiveness of the two species $(14,15)$.

The protein pattern of Bakos strains A, B, C, and $\mathrm{D}$ of $H$. parasuis (2; K. Bakos, Ph.D. thesis, Veterinar medicinska, Anstalt, Stockholm, 1955) permits the distinction of at least two separate patterns, that of strains $A, C$, and $D$ on the one hand and that of strain $B$ on the other. An atypical pattern was obtained from the field strains, suggesting a third group. These observations indicate a certain heterogeneity among $H$. parasuis strains. This is not surprising since $H$. parasuis has been inadequately investigated. The pattern obtained with the small number of strains studied suggests that strains isolated from Glässer syndrome and associated with pattern $B$ are quite homogeneous and different from the respiratory strains, which are associated with the pattern of strains A, C, and D. This observation and the exact status of the $H$. parasuis groups have to be examined further in studies employing more field strains and the newly established neotype strains of the various Haemophilus species.

Numerical taxonomy studies have shown that haemophili are closely related to pasteurellae and actinobacilli but not to brucellae, moraxellae, and bordetellae (13). The results obtained here by PAGE of the cell proteins of a few strains seem to agree with the results obtained by numerical taxonomy and demonstrate the feasibility of using this technique in taxonomic studies of these bacteria.

In summary, this investigation of the protein patterns of porcine strains of Haemophilus shows the great possibilities which PAGE offers for studying the relationships of various bacteria, provided that standard conditions are used. Our aim was not to draw taxonomic conclusions but to determine the potential use of PAGE in taxonomic studies of the haemophili. A comprehensive taxonomic study would have to be done more systematically and would have to involve the customary phenetic and genetic criteria.

\section{REPRINT REQUESTS}

Address reprint requests to: Prof. J. Nicolet, Institute of Veterinary Bacteriology, University of Berne, LänggassStrasse 122, 3012 Berne, Switzerland.

\section{LITERATURE CITED}

1. Ames, G. F.-L. 1974. Resolution of bacterial proteins by polyacrylamide gel electrophoresis on slabs. J. Biol. Chem. 249:634-644.

2. Bakos, K., A. Nilsson, and E. Thal. 1952. Untersuchungen über Haemophilus suis. Nord. Veterinaer Med. 4: 241-255.

3. Brückler, J., and H. Blobel. 1970. Vertikale Polyacrylamid-Gel Disk-Elektrophorese von StaphylokokkenProteinen. Zentralbl. Bakteriol. Parasitenkd. Infektionskr. Hyg. Abt. 1 Orig. 213:161-169.

4. Chrambach, A., R. A. Reisfeld, M. Wickofi, and J. Zaccari. 1967. A procedure for rapid and sensitive staining of protein fractionated by polyacrylamide gel electrophoresis. Anal. Biochem. 20:150-154.

5. Daniels, M. J., and B. M. Meddins. 1973. Polyacrylamide gel electrophoresis of mycoplasma proteins in sodium dodecyl sulphate. J. Gen. Microbiol. 76:239242.

6. Dellinger, J. D., and D. E. Jasper. 1972. Polyacrylamide gel electrophoresis of cell proteins of Mycoplasma isolated from cattle and horses. Am. J. Vet. Res. 33:769775 .

7. Gottlieb, D., and P. M. Hepden. 1966. The electrophoretic movement of proteins from various streptomyces species as a taxonomic criterion. J. Gen. Microbiol. 44: 95-104.

8. Haas, H., Y. Davidson, and T. Sacks. 1972. Taxonomy of mycobacteria studied by polyacrylamide gel electrophoresis of cell proteins. J. Med. Microbiol. 5:51-37.

9. Hartree, E. F. 1972. Determination of protein: a modification of the Lowry method that gives a linear photometric response. Anal. Biochem. 48:422-427.

10. Hudson, B. W., and T. J. Quan. 1975. Electrophoretic studies of the yersiniae. Am. J. Trop. Med. Hyg. 24: 968-973.

11. Inouye, M., and A. B. Pardee. 1970. Changes of membrane proteins and their relation to deoxyribonucleic acid synthesis and cell division of Escherichia coli. J. Biol. Chem. 21:5813-5819.

12. Inouye, M., and M. Yee. 1973. Homogeneity of envelope proteins of Escherichia coli separated by gel electrophoresis in sodium dodecyl sulfate. J. Bacteriol. 113: 304-312.

13. Johnson, R., and P. H. A. Sneath. 1973. Taxonomy of 
Bordetella and related organisms of the families Ach romobacteriaceae, Brucellaceae, and Neisseriaceae. Int. J. Syst. Bacteriol. 23:381-404.

14. Kilian, M. 1976. A taxonomic study of the genus Haemophilus with the proposal of a new species. J. Gen. Microbiol. 93:9-62.

15. Kilian, M., J. Nicolet, and E. L. Biberstein. 1978. Biochemical and serological characterization of Haemophilus pleuropneumoniae (Matthews and Pattison, 1961) Shope 1964 and proposal of a neotype strain. Int. J. Syst. Bacteriol. 28:20-26.

16. Larsen, S. A., S. T. Bickham, T. M. Buchanan, and W. T. Jones. 1971. Polyacrylamide gel electrophoresis of Corynebacterium diphtheriae: a possible epidemiological aid. Appl. Microbiol. 22:885-890.

17. Larsen, S. A., C. D. Webb, and M. D. Moody. 1969. Acrylamide gel electrophoresis of group A streptococcal cell walls. Appl. Microbiol. 17:31-33.

18. Lund, B. M. 1965. A comparison by the use of gel electrophoresis of soluble protein components and esterase enzymes of some group D streptococci. J. Gen. Microbiol. 40:413-419.

19. Morowitz, H. J., and T. M. Terry. 1965. Characterization of the plasma protein membrane of Mycoplasma laidlawii. Biochim. Biophys. Acta 183:276-294.

20. Morris, J. A. 1973. The use of polyacrylamide gel electrophoresis in taxonomy of Brucella. J. Gen. Microbiol. 76:231-237.

21. Morris, J. A., and R. W. A. Park. 1973. A comparison using gel electrophoresis of cell proteins on campylobacteria (vibrios) associated with infertility, abortion and swine dysentery. J. Gen. Microbiol. 78:165-178.

22. Neumann, U., and K. H. Hinz. 1977. Elektrophoretische Auftrennung von Haemophilus-Proteinen im Polyacrylamid-Gel. Zentralbl. Bakteriol. Parasitenkd. Infektionskr. Hyg. Abt. 1 Orig. Reihe A 238:244-250.

23. Nicolet, J. 1971. Sur l'hémophilose du porc. III. Différenciation sérologique de Haemophilus parahaemolyticus. Zentralbl. Bakteriol. Parasitenkd. Infektionskr. Hyg. Abt. 1 Orig. Reihe A 216:487-495.

24. Noble, R. C., and S. C. Schell. 1978. Acrylamide gel electrophoresis of proteins of Neisseria gonorrhoeae as an epidemiological tool. Infect. Immun. 19:178-186.

25. Omland, T. 1964. Serological studies on Haemophilus influenzae and related species. Acta Pathol. Microbiol. Scand. 62:79-88.

26. Osborn, M. J., J. E. Gander, E. Parisi, and J. Carson. 1972. Mechanism of assembly of the outer membrane of Salmonella typhimurium. J. Biol. Chem. 247:39623972.

27. Paroz, P., M. KrawinkJer, and J. Nicolet. 1977. Verwendung der Polyacrylamid-Gel-Elektrophorese in der Diagnostik von Nutztier-Mykoplasmen. Zentralbl. Veterinaermed. Reihe B 24:668-677.

28. Razin, S. 1968. Mycoplasma taxonomy studied by electrophoresis of cell proteins. J. Bacteriol. 96:687-694.

29. Razin, S., and S. Rottem. 1967. Identification of Mycoplasma and other microorganisms by polyacrylamide gel electrophoresis of cell proteins. J. Bacteriol. 94:
1807-1810.

30. Rosenbusch, J. P. 1974. Characterization of the major envelope protein of Escherichia coli. J. Biol. Chem 249:8019-8029.

31. Russell, R. R. R., K. G. Johnson, and I. J. McDonald. 1975. Envelope proteins of Neisseria. Can. J. Microbiol. 21:1519-1534.

32. Sacks, T. G., H. Haas, and S. Razin. 1969. Polyacrylamide gel electrophoresis of cell proteins of Enterobac. teriaceae. Isr. J. Med. Sci. 5:49-55.

33. Schnaitman, C. A. 1970. Protein composition of the cell wall and cytoplasmic membrane of Escherichia coli. J. Bacteriol. 104:890-901.

34. Schnaitman, C. A. 1973. Outer membrane proteins of Escherichia coli. I. Effect of preparative conditions on the migration of protein in polyacrylamide gels. Arch. Biochem. Biophys. 157:541-552.

35. Schnaitman, C. A. 1973. Outer membrane proteins of Escherichia coli. II. Heterogeneity of major outer membrane polypeptides. Arch. Biochem. Biophys. 157:553560 .

36. Schnaitman, C. A. 1974. Outer membrane proteins of Escherichia coli. III. Evidence that the major protein of Escherichia coli 0111 outer membrane consists of four distinct polypeptide species. J. Bacteriol. 118:442454.

37. Schnaitman, C. A. 1974. Outer membrane proteins of Escherichia coli. IV. Differences in outer membrane proteins due to strain and cultural differences. J. Bacteriol. 118:454-465.

38. Sorenson, W. G., H. W. Larsh, and S. Hamp. 1971. Acrylamide gel electrophoresis of proteins from Aspergillus species. Am. J. Bot. 58:588-593.

39. Theodore, S. T., J. R. King, and R. M. Cole. 1969. Identification of L-forms by polyacrylamide gel electrophoresis. J. Bacteriol. 97:495-499.

40. Theodore, S. T., J. G. Tully, and R. M. Cole. 1971. Polyacrylamide gel identification of bacterial L-forms and Mycoplasma species of human origin. Appl. Microbiol. 21:272-277.

41. Theodore, S. T., J. R. King, J. G. Tully, and R. M. Cole. 1970. Polyacrylamide gel patterns of microorganisms. Dev. Ind. Microbiol. 11:122-138.

42. Thompson, D. A., and D. L. Mould. 1975. Protein electrophoretic pattern of Pasteurella haemolytica. Res. Vet. Sci. 18:342-343.

43. White, T. G., and F. K. Mirikitani. 1976. Some biological and physical-chemical properties of Erysipelothrix rhusiopathiae. Cornell Vet. 66:152-163.

44. Wu, M. C., and E. C. Heath. 1973. Isolation and characterization of lipopolysaccharide protein from Esche. richia coli. Proc. Natl. Acad. Sci. U.S.A. 70:2572-2576.

45. Zollinger, W. D., D. L. Kasper, B. J. Vettri, and M. S. Artenstein. 1972. Isolation and characterization of a native cell wall complex from Neisseria meningitidis. Infect. Immun. 6:835-851.

46. Zoon, K. C., and J. J. Scocca. 1975. Constitution of the cell envelope of Haemophilus influenzae in relation to competence for genetic transformation. J. Bacteriol. 123: $666-677$. 